\title{
FATIGUE LIFE ASSESSMENT OF WASTE STEEL REUSED AS TSUNAMI BUOY KEEL STRUCTURES: A CASE STUDY
}

\author{
Ketut Suastika ${ }^{1}$, Sahlan ${ }^{2}$, Wibowo H. Nugroho ${ }^{2}$, Achmad Zubaydi $^{1}$, Mohammad N. Misbah $^{1}$, \\ Murdjito $^{3}$ \\ ${ }^{1}$ Department of Naval Architecture, Faculty of Marine Technology, Institut Teknologi Sepuluh \\ Nopember (ITS), Kampus ITS Sukolilo, Surabaya 60111, Indonesia \\ ${ }^{2}$ Indonesian Hydrodynamics Laboratory (IHL), BPPT, Kompleks Kampus ITS Sukolilo, Surabaya 60111, \\ Indonesia \\ ${ }^{3}$ Department of Ocean Engineering, Faculty of Marine Technology, Institut Teknologi Sepuluh \\ Nopember (ITS), Kampus ITS Sukolilo, Surabaya 60111, Indonesia
}

(Received: July 2017 / Revised: December 2018 / Accepted: June 2019)

\begin{abstract}
Waste steel from used ship propeller shafts is reused for the keel structures of InaTEWS buoys. Because of the application of waste material, fatigue life assessment is critical. The purpose of this study is to assess the mechanical and fatigue properties of the waste material and to estimate the fatigue life of the keel structure as a result of sea wave loading. Material tests, fatigue tests and model tests were performed to obtain the parameters required for the estimation of the fatigue life, together with application of the spectral analysis method, including the effects of spectral band width. Chemical and tensile tests identified the material as low-carbon steel, with mechanical properties comparable to AISI 1035 steel. The fatigue tests resulted in an $S$ - $N$ curve $\left(N S^{m}=K\right)$ with $m=7.7$ and $K=3.2 \times 10^{24}$, showing a lower fatigue strength than AISI 1035 steel. The observed reduction in fatigue strength is ascribed to the previous use of the shaft. The calculated fatigue life based on the experimental $S$ - $N$ curve and the observed in-situ wave data is approximately 9.5 years, with a safety factor of 5 .
\end{abstract}

Keywords: Fatigue life; Keel structure; Spectral analysis; Tsunami buoy; Waste steel

\section{INTRODUCTION}

The Indonesia tsunami early warning system (InaTEWS) utilizes an array of surface buoys, some of which are installed and operated off the west coast of Sumatra and others off the south coast of Java (Nugroho \& Sahlan, 2008; Yustiawan et al., 2013; BMKG, 2019). These stretches of Indonesian water are prone to tsunami events. For example, the Aceh tsunami of 2004 hit the west coast of northern Sumatra; the Mentawai tsunamis of 2004 and 2010 affected the Mentawai Islands off the west coast of West Sumatra; while the Banten and Lampung tsunami of 2018 hit the coast of South Lampung in southern Sumatra and the coast of Serang, Banten, in western Java (the Sunda Strait).

Such tsunami events result in loss of infrastructure, goods and lives. For example, in the 2004 Aceh tsunami, 300,000 lives were lost (Couldrey \& Morris, 2005), while in the 2010 Mentawai tsunami, more than 20 villages were hit, displacing more than 20,000 people and affecting about 4,000 households (BBC News Online, 2010). The above examples underscore the importance of

\footnotetext{
*Corresponding author's email: ksuastika69@gmail.com, Tel. +62-31-5964182, Fax. +62-31-5964182 Permalink/DOI: https://dx.doi.org/10.14716/ijtech.v10i4.501
} 
such a tsunami early warning system, particularly for saving lives.

The full concept of the InaTEWS is described in BMKG (2019), while in this study only the buoy system is considered. An ocean bottom unit (OBU) records the changes in water pressure due to seismic movements prior to a tsunami event and sends the readings to the surface buoy via an acoustic signal. The recorded signal is then transmitted to a ground station by a satellite for early warning and/or further analyses.

BTI-G2 buoys are some of the surface buoys utilized in the InaTEWS. They were developed through a series of development stages and designed for application in deep water. In contrast, the earlier BTI-G1 type buoys, which were modified versions of the so-called ex-seawatch BPPT buoys, were designed and applied for environmental data collection in relatively shallow water (the Java Sea). The principal dimensions of the BTI-G2 buoys are as follows: diameter $D=2.50$ $\mathrm{m}$, height $H=1.68 \mathrm{~m}$ and volume of displacement $\nabla=2.45 \mathrm{~m}^{3}$ at draught $T=0.50 \mathrm{~m}$. Figure 1 shows a launch test of a BTI-G2 buoy from an Indonesian Baruna Jaya BPPT research vessel.

Each surface buoy is held in position by the use of a single-taut mooring line, which is connected to the buoy hull using a keel structure (see Figure 1). Different configurations for this structure have been designed and manufactured during the development of the buoys. The one investigated in this study is shown in Figure 2 (Nugroho \& Sahlan, 2008; Sahlan, 2011). The keel structure was manufactured from a used ship propeller shaft, which had been in service for approximately 20 years, and was considered as waste material.

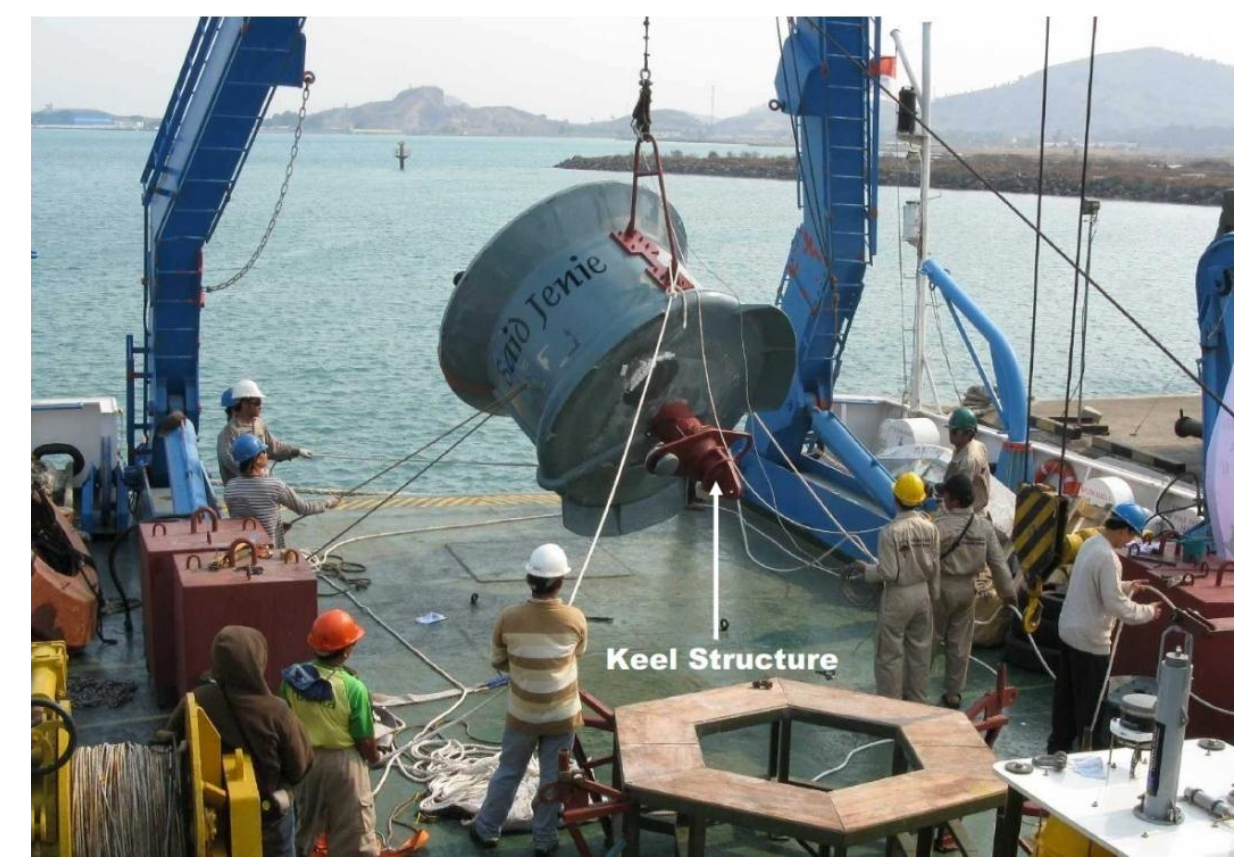

Figure 1 Launch test of a BTI-G2 buoy from an Indonesian Baruna Jaya BPPT research vessel

Reuse and minimization of waste (Kusrini et al., 2018) through effective collaboration between stakeholders (Nursin et al., 2018) are key issues in sustainable development. Furthermore, waste materials such as used propeller shafts are traded freely in Indonesia and can be obtained easily at a relatively low price. There are therefore two main reasons for reusing such waste steel, namely: environmental sustainability and cost saving.

The use of waste material makes the assessment of the fatigue life of the buoy keel structure critical. Furthermore, fatigue life assessment is important for marine structures due to the cyclic nature of wave loading (ABS, 2005; DNV, 2016). The purpose of this study is to assess the 
mechanical and fatigue properties of the waste material and to estimate the fatigue life of the keel structure due to sea wave loading.
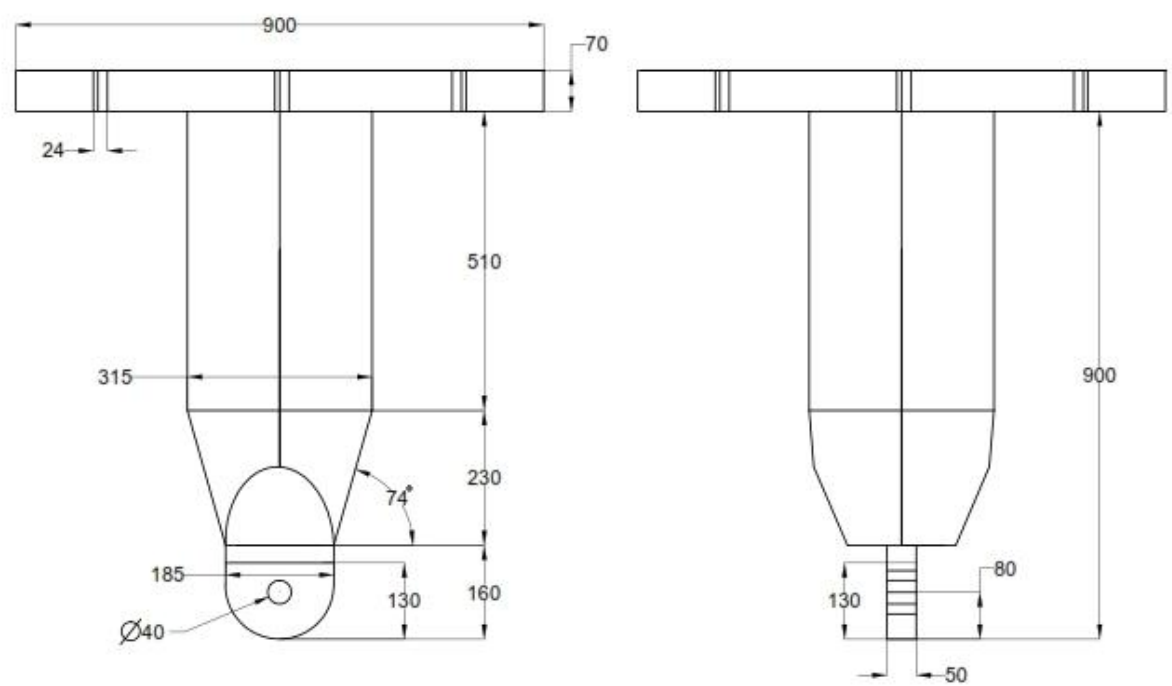

Figure 2 Front and side views of the keel structure investigated in this study (unit in $\mathrm{mm}$ ) (Nugroho \& Sahlan, 2008; Sahlan, 2011)

\section{METHOD}

\subsection{Material Tests}

Table 1 summarizes the chemical composition of the keel material, obtained from a chemical test using a specimen with length $l=40 \mathrm{~mm}$, width $w=40 \mathrm{~mm}$ and thickness $t=10 \mathrm{~mm}$, tested at five locations using an ARL spectrometer. Comparison with the carbon steel data provided by Spotts (1985) and Huyett (2004) shows that the observed chemical composition is comparable to AISI 1035 steel. The percentage of carbon, which is in the range between 0.20 and $0.30 \%$, is common for shaft applications.

Table 1 Chemical composition of the keel material

\begin{tabular}{cccc}
\hline Element & $\%$ & Element & $\%$ \\
\hline $\mathrm{Fe}$ & 98.4 & $\mathrm{Al}$ & 0.0026 \\
$\mathrm{C}$ & 0.25 & $\mathrm{Cr}$ & 0.077 \\
$\mathrm{Mn}$ & 0.67 & $\mathrm{Cu}$ & 0.16 \\
$\mathrm{P}$ & 0.019 & $\mathrm{Ni}$ & 0.042 \\
$\mathrm{~S}$ & 0.018 & $\mathrm{Mo}$ & 0.0095 \\
$\mathrm{Si}$ & 0.29 & $\mathrm{Nb}$ & 0.0011 \\
$\mathrm{Sn}$ & 0.0082 & $\mathrm{Co}$ & 0.0067 \\
\hline
\end{tabular}

Table 2 Mechanical properties of the keel material compared to AISI 1035 and 1038 hot-rolled steels

\begin{tabular}{lccc}
\hline Material & $\begin{array}{c}\text { Yield strength } \\
\sigma_{y}(\mathrm{MPa})\end{array}$ & $\begin{array}{c}\text { Tensile strength } \\
\sigma_{u}(\mathrm{MPa})\end{array}$ & $\begin{array}{c}\text { Modulus of elasticity } \\
E(\mathrm{GPa})\end{array}$ \\
\hline Surface (S) & 283 & 492 & 196 \\
Core (C) & 283 & 500 & 197 \\
AISI 1035 & 270 & 495 & 196 \\
AISI 1038 & 285 & 515 & 200 \\
\hline
\end{tabular}


Table 2 summarizes the results from the tensile tests, performed according to ASTM A370 (ASM, 2001). A distinction was made between surface (S) and core (C) specimens, as shown in Figure 3. Table 2 shows that the mechanical properties of the keel material are comparable to AISI 1035 steel, consistent with the results obtained from the chemical test described above. The differences in mechanical properties between the surface (S) and core $(\mathrm{C})$ materials are relatively small and within the normal scatter for engineering steels.
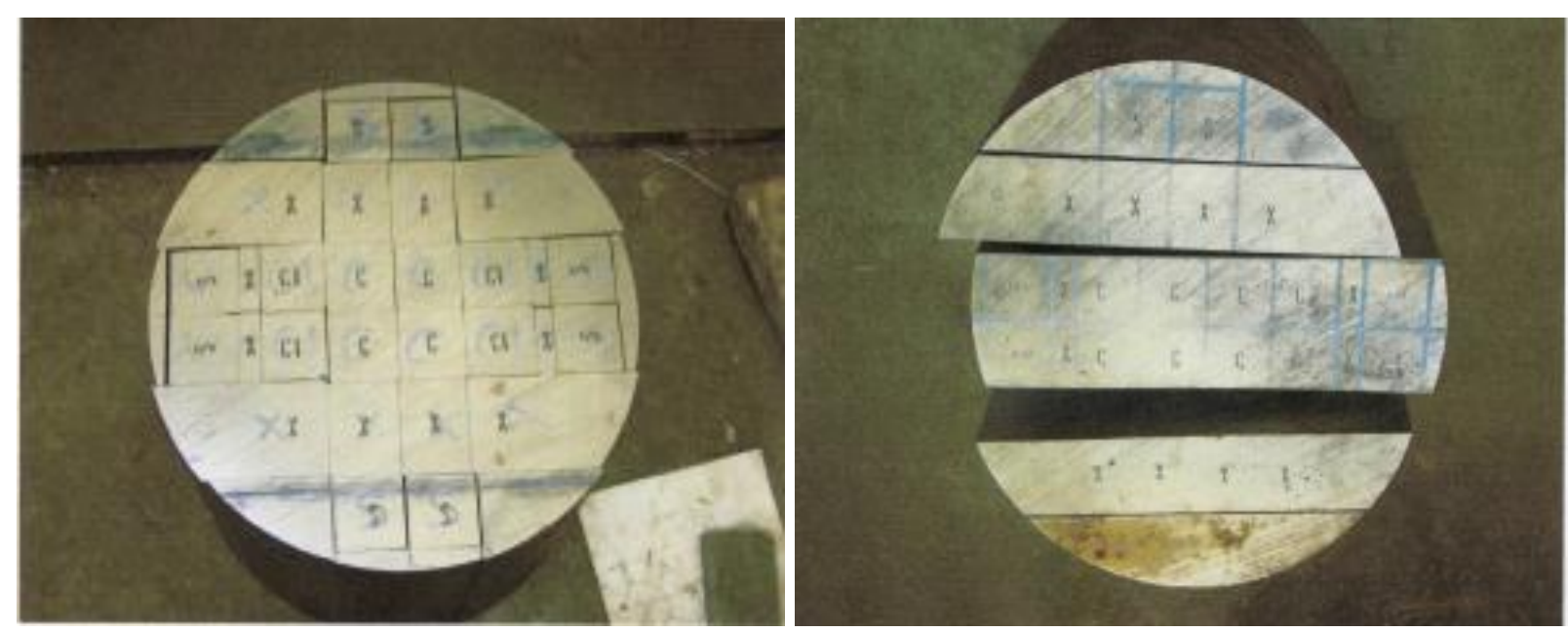

Figure 3 Locations of the surface (S) and core (C) specimens in the cross section of the propeller shaft

\subsection{Fatigue Tests}

Fatigue tests were conducted according to ASTM E466 (ASM, 2002). Ten specimens were designed and manufactured with tangentially blending fillets between the uniform test section and the ends. Tests with sinusoidally-varying axial loading (constant-amplitude tests) were performed at room temperature at a frequency of $20 \mathrm{~Hz}$ and stress ratio of $R=0$, which is defined as:

$$
R=\frac{\sigma_{\min }}{\sigma_{\max }}
$$

where $\sigma_{\min }$ is the minimum stress and $\sigma_{\max }$ is the maximum stress. In the present case, $R=\sigma_{\min }=$ 0 ; that is, full tensile load. In this case, the maximum stress is equal to the stress range.

The fatigue test data are represented in the form of an $S-N$ curve, with an equation given as

$$
N S^{m}=K
$$

where $S$ is the stress range and $N$ is the number of cycles until failure. Furthermore, $m$ and $K$ are material constants. To estimate the values of $m$ and $K$, a regression analysis procedure, as recommended by the IIW (Schneider \& Maddox, 2003), was applied. This resulted in $m=7.7$ and $K=3.2 \times 10^{24}$ (slope $b=-1 / m=-0.13$ ). The goodness of fit between Equation 2 and the experimental data is characterized by the coefficient of determination $r^{2}=0.993$. The $S-N$ curve is shown in Figure 4.

An empirical formula recommended by ASM (1990), which relates the constant $K$ to $m$, is given as follows:

$$
K=\frac{\left(2 \sigma_{f}^{\prime}\right)^{m}}{2}
$$

where $\sigma_{f}^{\prime}=\sigma_{u}+345=845 \mathrm{MPa}$ is the fatigue strength coefficient. Using Equation 3 with $\sigma_{f}^{\prime}=$ 845 and $m=7.7$ results in $K=3.3 \times 10^{24}$, which is in good agreement with the observed value of the constant $K$. 
A comparison of the experimental $S$ - $N$ curve with those for AISI 1006, 1020 and 1035 steels (see Figure 4 and Table 3 ) shows that the $S$ - $N$ curve (fatigue strength) of the keel material lies between the curves for AISI 1006 and 1020 steels. It is lower than that of AISI 1035 steel, although the chemical and mechanical properties of the two are comparable, as discussed in subsection 2.1. The observed reduction in fatigue strength is ascribed to the previous use of the shaft.

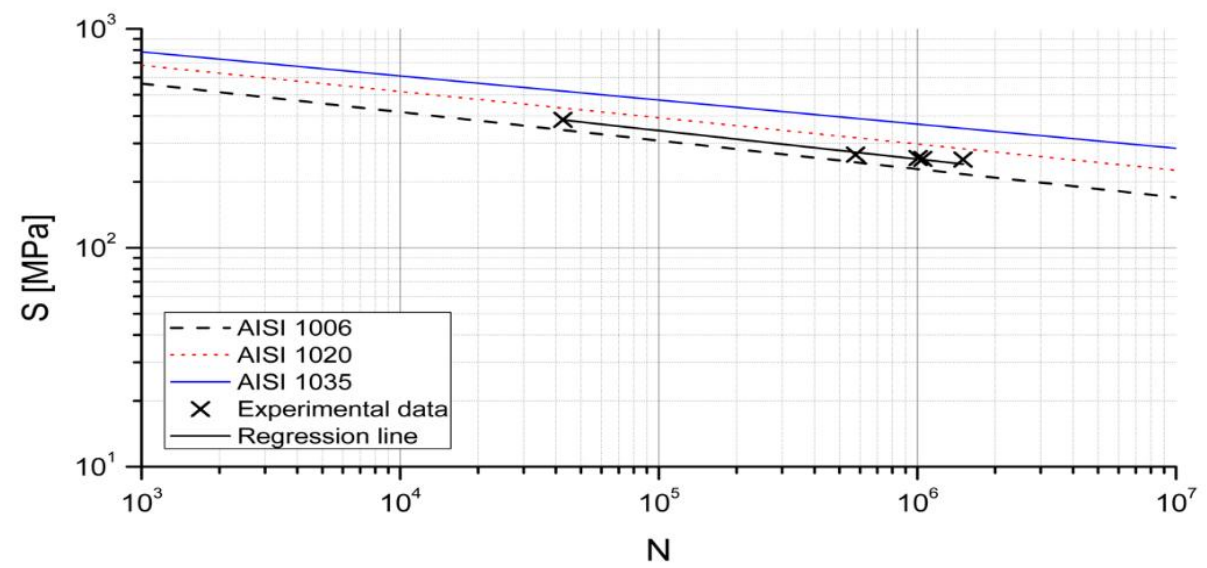

Figure $4 S$ - $N$ curve obtained from the fatigue tests compared to those for AISI 1006, 1020 and 1035 steels

Table 3 Fatigue strength properties of the keel material compared to AISI 1006, 1020 and 1035 steels (ASM, 1990)

\begin{tabular}{lccc}
\hline \multicolumn{1}{c}{ Material } & $b$ & $m$ & $K$ \\
\hline AISI 1006 & -0.13 & 7.69 & $1.41 \times 10^{24}$ \\
Keel material & -0.13 & 7.70 & $3.2 \times 10^{24}$ \\
AISI 1020 & -0.12 & 8.33 & $4.06 \times 10^{26}$ \\
AISI 1035 & -0.11 & 9.09 & $2.07 \times 10^{29}$ \\
\hline
\end{tabular}

\subsection{Model Tests}

The random character of the stress fluctuation in the keel structure due to sea wave loading in a particular sea state is represented by a stress spectrum. This stress spectrum can be calculated if the stress response amplitude operator (RAO) and the wave spectrum are provided. To obtain the stress RAO, model tests on a scale of 1:16 were performed in a wave basin at the Indonesian Hydrodynamics Laboratory (IHL), BPPT, Surabaya, Indonesia.

In the model tests, the mooring force was measured by using a load cell. The mooring force RAO, denoted as $\left|H_{\mathrm{F} \zeta}(\omega)\right|$, was determined experimentally by conducting tests on regular waves with different amplitudes and frequencies (see Figure 5a). To verify the results from these regular wave tests, tests were performed on irregular waves, which were represented by a JONSWAP spectrum with a significant wave height of $H_{s}=2.0 \mathrm{~m}$ and a peak period of $T_{p}=6.0 \mathrm{~s}$. This wave condition is representative of the sea state at the buoy location.

Stress RAO is estimated from the mooring force RAO using the following relation:

$$
\left|H_{\sigma \varsigma}(\omega)\right|=\frac{\mathrm{SCF}}{A}\left|H_{F \varsigma}(\omega)\right|
$$

where $\left|H_{\sigma \zeta}(\omega)\right|$ is the stress RAO, $\left|H_{\mathrm{F} \zeta}(\omega)\right|$ is the mooring force RAO, $A$ is the area of the cross section of the keel structure $\left(A=7250 \mathrm{~mm}^{2}\right)$ and SCF is the stress concentration factor. 


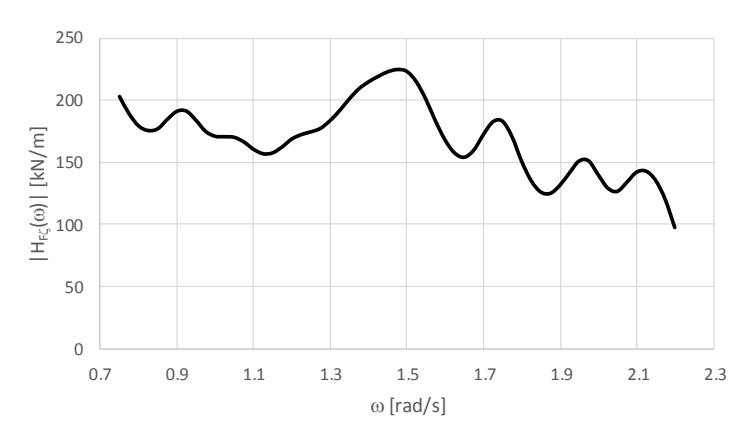

(a)

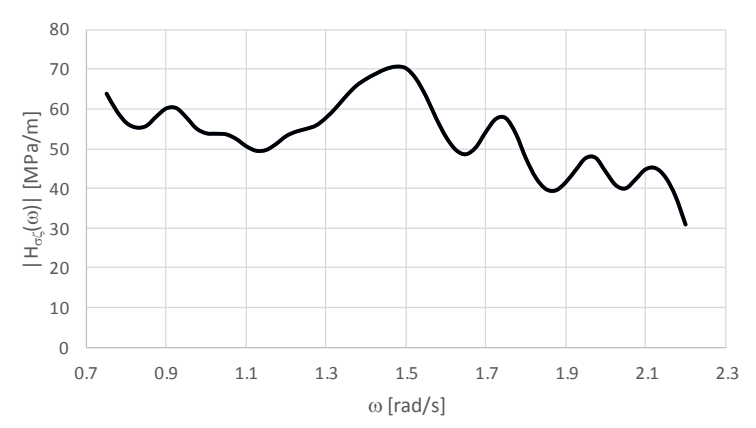

(b)

Figure 5 (a) Mooring force RAO and (b) stress RAO

To obtain the stress RAO, it is necessary to calculate the SCF. To do this, the keel structure was modeled using a finite element method (FEM) (Sahlan, 2011), which resulted in SCF $=2.28$. To verify the results from the FEM calculations, they were compared with those obtained by Broek (1982) from a case in which the keel structure was modeled simply as a plate with a hole:

$$
\mathrm{SCF}=2+\left(1-\frac{d}{w}\right)^{3}
$$

where $d$ is the hole diameter and $w$ is the width of the keel structure. For the case under consideration, Equation 5 gives $\mathrm{SCF}=2.48$, which is $8 \%$ larger than the result obtained from the FEM modeling. In the following calculations, the $\mathrm{SCF}=2.28$ will be used.

Using Equation 4 with $\mathrm{SCF}=2.28, A=7250 \mathrm{~mm}^{2}$ and $\left|H_{\mathrm{F} \zeta}(\omega)\right|$, as shown in Figure $5 \mathrm{a}$, the resulting stress RAO is shown in Figure $5 \mathrm{~b}$. The shape of the stress RAO curve is similar to that of the mooring force RAO curve, which was expected, as the SCF is assumed to be frequency independent. Furthermore, there are no dominant peaks in the stress RAO curve, as is intended in the design of the buoys in order to avoid resonant response, particularly in the frequency range with significant wave energy.

Having determined the stress RAO, the stress spectrum can be calculated from the relationship:

$$
S_{\sigma \sigma}(\omega)=\left|H_{\sigma \zeta}(\omega)\right|^{2} S_{\zeta \varsigma}(\omega)
$$

where $S_{\sigma \sigma}(\omega)$ is the stress spectrum, $S_{\zeta \zeta}(\omega)$ is the wave spectrum and $\left|H_{\sigma \zeta}(\omega)\right|$ is the stress RAO. Equation 6 is used to calculate the stress spectra for the different sea states represented by the wave scatter diagram. This diagram was obtained from one-year wave observations at the buoy location with the coordinate E 108 $34^{\prime} 17^{\prime}$ ', S 10³9'98', (Yustiawan et al., 2013). The wave scatter diagram represents the number of occurrences of different sea states (or durations of sea states in a year), each of which is characterized by a significant wave height $H_{s}$ and an average zero up-crossing wave period $T_{z}$. For the fatigue life calculations, JONSWAP wave spectra are used to model the sea states.

For verification purposes, Figure 6 shows a comparison between the prototype stress spectrum calculated from Equation 6 and that estimated directly from the measured stress time series using Welch's method (Welch, 1970). The two spectra show good agreement considering the area under the curve $m_{0}=673.1 \mathrm{MPa}^{2}$ for the spectrum calculated from Equation 6, and $m_{0}=672.3$ $\mathrm{MPa}^{2}$ for the spectrum estimated from Welch's method. 


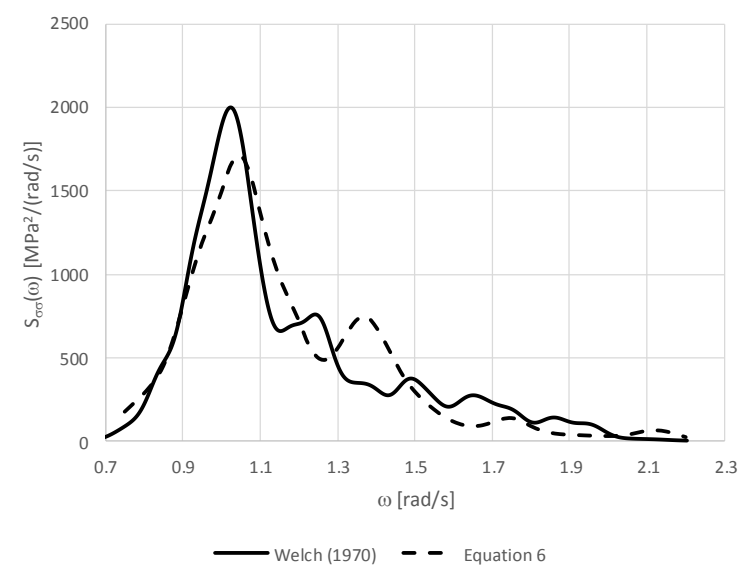

(a)

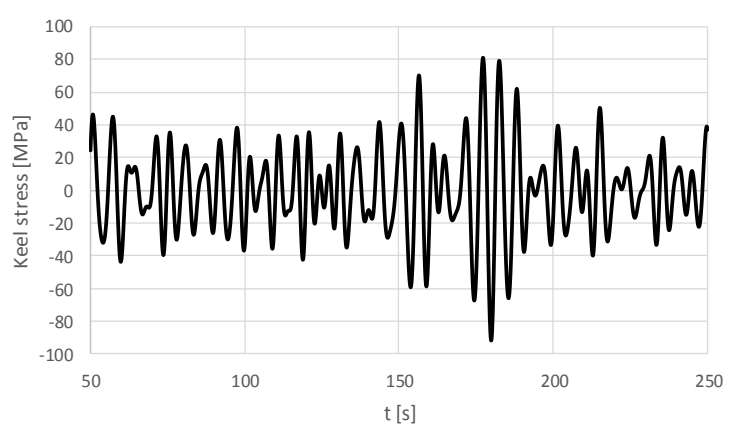

(b)

Figure 6 (a) Comparison between the stress spectra calculated from Equation 6 and estimated directly from the measured stress time series, for which a segment is shown in (b), using Welch's method

\section{RESULTS AND DISCUSSION}

The fatigue life of the keel structure was estimated using a spectral fatigue analysis method, taking into account the effects of the spectral band width. Before estimating the fatigue life of the structure exposed to different sea states, the results from spectral fatigue calculations for the case of the sea state as considered in the model tests were compared each other. In addition, these results were verified using the result obtained from a time-domain analysis, which utilized a rainflow cycle counting method (Rychlick, 1987) and Miner-Palmgren's rule.

Table 4 Fatigue damage rates calculated using different methods for the sea state considered in the model tests

\begin{tabular}{lc}
\hline \multicolumn{1}{c}{ Method } & $D$ (per hour) \\
\hline Rain-flow cycle counting (time domain) & $8.6 \times 10^{-7}$ \\
Rayleigh (narrow-banded) approximation & $9.2 \times 10^{-7}$ \\
Kam \& Dover (1988) & $8.1 \times 10^{-7}$ \\
Hancock \& Gall (1985; Formula A) & $8.2 \times 10^{-7}$ \\
Dirlik (1985) & $8.7 \times 10^{-7}$ \\
\hline
\end{tabular}

Table 4 summarizes the fatigue damage rates calculated from the time-domain analysis, the narrow-banded (Rayleigh) approximation (Baltrop \& Adams, 1991) and those with band width effects taken into account, following Dirlik (1985), Kam and Dover (1988) and Hancock and Gall (1985). Table 4 shows that the rate of fatigue damage calculated from the time-domain analysis is $8.6 \times 10^{-7}$ per hour, while that calculated from the Rayleigh approximation is $9.2 \times 10^{-7}$ per hour, which is $6 \%$ greater. Results closer to that of the time-domain analysis can be obtained by taking into account band width effects; among those, the best approximation is provided by Dirlik (1985) with a rate of fatigue damage of $8.7 \times 10^{-7}$ per hour. The above findings are consistent with the results reported in previous studies (Halfpenny, 1999).

Therefore, Dirlik's approximation is used for the estimation of the fatigue life of the keel structure. The total rate of fatigue damage in a year is calculated as the sum of all the fatigue damage rates due to different sea states in the same period. The resulting total rate of fatigue damage is $D_{t o t}=2.1 \times 10^{-2}$ per year and the fatigue life, calculated as $1 / D_{t o t}$, is approximately 47 years. No safety factor was included in the calculation of the fatigue life described above; inclusion of such a factor will result in a fatigue life lower than 47 years. ABS (2003) recommends 
a minimum safety factor of 5, which would result in a fatigue life of roughly 9.5 years (47 years divided by 5 ).

Earlier studies have considered the fatigue life of the buoy keel structure. Sahlan (2011) utilized a deterministic method based on Miner-Palmgren's rule to estimate it, while Yustiawan et al. (2013) applied a spectral fatigue method based on the Rayleigh approximation, assuming a narrow-banded process for the wave loading. Suastika et al. (2014) also utilized a spectral fatigue method but included effects of the spectral band width, basing their estimation on one sea state observation. In all the above studies, lower fatigue lives than that found in this study were found. Without a safety factor, Sahlan (2011) estimated the fatigue life of the keel structure to be approximately 7.5 years, Yustiawan et al. (2013) estimated it at approximately 11 years, while Suastika et al.'s (2014) estimatation was approximately 15 years.

The discrepancy between their results of fatigue life estimation and that of this study can be mainly ascribed to two reasons:

1) In all the previous studies, the authors did not follow the IIW procedure (Schneider \& Maddox, 2003) in determination of the $S-N$ curve from the fatigue test data, while in this study it was followed. It is well-known that the result of a fatigue life calculation is sensitive to the $S$ - $N$ curve used (eg. Wang \& Cheng, 2003).

2) Reanalysis of the mooring force time series obtained from the model tests found a spurious periodical trend in the data, which was not removed before determining the stress ranges in the deterministic analysis reported by Sahlan (2011), or before determining the stress RAO and the stress spectra in the spectral analysis methods reported by Yustiawan et al. (2013) and Suastika et al. (2014).

By following the IIW procedure and removing (filtering) the spurious periodical trend observed in the data, it is expected that the fatigue life obtained in this study is more accurate than those reported previously.

The spectral analysis method is straightforward and much faster than a typical time-domain fatigue life calculation based on the stress time series, which is consistent with results from other studies and recommended standards (eg. Tromans \& Suastika, 1998; ABS, 2005).

A linear $S-N$ curve has been used in this study, not a bi-linear one (DNV, 2016), because of the relatively high uncertainty in the slope estimation of the $S-N$ curve for oscillations with relatively small stress ranges. These relatively small oscillations $\left(\mathrm{N}>10^{7}\right.$ cycles) were not covered in the experimental data. Using a bi-linear $S-N$ curve will result in a longer fatigue life than that presented here. Furthermore, the effects of vortex-induced vibration (eg. Tognarelli et al., 2013) in the fatigue life estimation were not included because of a lack of current in-situ data.

\section{CONCLUSION}

Waste steel from a used ship propeller shaft was reused as the keel structure for InaTEWS buoys. Material and fatigue tests show that the static mechanical properties of the material are comparable to AISI 1035 steel, but that its cyclic fatigue strength is lower. Its fatigue strength lies between those for AISI 1006 and 1020 steels. The observed reduction in fatigue strength is ascribed to the previous use of the shaft. The fatigue life of the keel structure, calculated using a spectral analysis method, including effects of the spectral band width, and based on the experimental $S$ - $N$ curve together with the observed in-situ wave data, is approximately 47 years without a safety factor. Including a safety factor of 5, as recommended by ABS (2003), results in a fatigue life of roughly 9.5 years. The spectral analysis method is straightforward and much faster than a typical time-domain fatigue life calculation based on the stress time series. The uncertainty of the result obtained from the method depends on the uncertainties in the 
experimentally determined $S-N$ curve, the assumed spectra representing the sea states, and the calculation models used. A reliability study (eg. Khan \& Ahmad, 2014) is recommended to quantify the above-mentioned uncertainties.

\section{ACKNOWLEDGEMENT}

The authors thank Baharuddin Ali, M.Eng. at the Indonesian Hydrodynamics Laboratory (IHL), BPPT, Surabaya, Indonesia for the useful discussions on the analysis methods of model test data and interpretations of the results. This research project was partly supported by the Ministry of Research, Technology and Higher Education of the Republic of Indonesia under grants no. 016452.28/IT2.11/PN.08/2014 and 003246.171/IT2.11/PN.08/2015.

\section{REFERENCES}

ABS, 2003. Guide for Fatigue Assessment of Offshore Structures. American Bureau of Shipping, Houston, TX 77060, USA

ABS, 2005. Spectral-based Fatigue Analysis for Floating Offshore Structures. American Bureau of Shipping, Houston, TX 77060, USA

ASM, 1990. Properties and Selection: Irons, Steels, and High-Performance Alloys. ASM Handbook, Volume 1, $10^{\text {th }}$ ed., ASM International, West Conshohocken, PA, USA, pp. 673688

ASM, 2001. ASTM A370: Standard Test Methods and Definitions for Mechanical Testing of Steel Products. ASTM International, West Conshohocken, PA, USA

ASM, 2002. ASTM E466: Standard Practice for Conducting Force Controlled Constant Amplitude Axial Fatigue Tests of Metallic Materials. ASTM International, West Conshohocken, PA, USA, pp. 1-5

Baltrop, N.D.P., Adams, A.J., 1991. Dynamics of Fixed Marine Structures. $3^{\text {rd }}$ Edition. Oxford, UK: Butterworth Heinemann

BBC News Online, 2010. Indonesia Tsunami: Death Toll Soars to 282. Available Online at https://www.bbc.com/news/world-asia-pacific-11632982

BMKG (Indonesian Agency for Meteorology, Climatology and Geophysics), 2019. InaTEWS: Indonesia Tsunami Early Warning System (in Bahasa). Available Online at https://inatews.bmkg.go.id/, Accessed on May 19, 2019

Broek, D., 1982. Elementary Engineering Fracture Mechanics. $3^{\text {rd }}$ Edition. The Hague, The Netherlands: Martinus Nijhoff Publisher

Couldrey, M., Morris, T., 2005. Tsunami: Learning from the Humanitarian Response. Forced Migration Review, Special Issue, pp. 1-52

Dirlik, T., 1985. Application of Computers in Fatigue Analysis. PhD Thesis, University of Warwick, UK

DNV, 2016. DNVGL-RP-C203: Fatigue Design of Offshore Steel Structures. Recommended Practice, Det Norske Veritas

Halfpenny, A., 1999. A Frequency Domain Approach for Fatigue Life Estimation from Finite Element Analysis. nCode International Ltd., Sheffield, UK. In: International Conference on Damage Assessment of Structures (DAMAS 99), Dublin, Ireland

Hancock, J.W., Gall, D.S., 1985. Fatigue under Narrow and Broad Band Stationary Loading. Final Report of the Cohesive Programme of Research and Development into the Fatigue of Offshore Structures, Marine Technology Directorate Ltd., London, UK

Huyett, G., 2004. Engineering Handbook, Technical Information. G.L. Huyett, Minneapolis, Kansas, USA 
Kam, J.C.P., Dover, W.D., 1988. Fast Fatigue Assessment Procedure for Offshore Structures under Random Stress History. In; Proceedings Institution of Civil Engineers, Part II, Research and Theory 85, pp. 689-700

Khan, R.A., Ahmad, S., 2014. Bi-linear Fatigue and Fracture Approach for Safety Analysis of an Offshore Structure. Journal of Offshore Mechanics and Arctic Engineering, Volume 136(2), pp. 1-7

Kusrini, E., Setiawan, E.A., Sofyan, N., 2018. Exploring Potential Materials, Science, and Technology for Improvements in Reusing Energy and Waste. International Journal of Technology, Volume 9(6), pp. 1085-1091

Nugroho, W.H., Sahlan, 2008. Pembuatan Buoyhull Tsunami dan Uji Apung dan Decay Test (Development of Tsunami Buoy Hulls: Floating and Decay Tests). Technical Report, Indonesian Hydrodynamics Laboratory (IHL), BPPT, Surabaya, Indonesia

Nursin, A., Latief, Y., Muchtar, K., Soeparto H.G., 2018. Cross-party Collaboration to Reduce Construction Waste to Design-build Projects. International Journal of Technology, Volume 9(4), pp. 751-765

Rychlick, I., 1987. A New Definition of the Rainflow Cycle Counting Method. International Journal of Fatigue, Volume 9(2), pp. 119-121

Sahlan, 2011. Prediksi Umur Kelelahan Struktur Keel Buoy Tsunami akibat Beban Gelombang (Fatigue Life Prediction of Tsunami Buoy Keel Structures due to Wave Loading). MSc Thesis, Faculty of Marine Technology, ITS Surabaya, Indonesia (in Bahasa)

Schneider, C.R.A., Maddox, S.J., 2003. Best Practice Guide on Statistical Analysis of Fatigue Data. Doc: IIW-XIII-WG1-114-03, Commission XIII-WG1, International Institute of Welding, UK

Spotts, M.F., 1985. Design of Machine Elements. $6^{\text {th }}$ Edition. Mechanical Engineering Department, Technological Institute of Northwestern University, Illinois, USA

Suastika, K., Sahlan, Nugroho, W.H., Zubaydi, A., Misbah, M.N., 2014. Fatigue-life Assessment of InaTEWS Tsunami Buoys. In: Proceedings $9^{\text {th }}$ International Conference on Marine Technology (Martec 2014), Paper No. MT-31, Surabaya, Indonesia

Tognarelli, M., Fontaine, E., Beynet, P., Santosa, M., Marcollo, H., 2013. Reliability-based Factors of Safety for Vortex Induced Vibration Fatigue using Field Measurements. Journal of Offshore Mechanics and Arctic Engineering, Volume 135(4), pp. 1-7

Tromans, P.S., Suastika, I.K., 1998. Spectral Response Surfaces, Designer Waves and the Ringing of Offshore Structures. In: Proceedings of the International OTRC Symposium, Texas, USA

Wang, X., Cheng, Z., 2003. Sensitivity of Fatigue Assessment to the Use of Different Reference $S-N$ Curves. In: Proceedings of OMAE 2003, $22^{\text {nd }}$ International Conference on Offshore Mechanics and Arctic Engineering, Cancun, Mexico

Welch, P.D., 1970. The Use of the Fast Fourier Transform for the Estimation of Power Spectra. IEEE Transactions on Audio and Electroacoustics, Volume AU-15(2), pp. 70-73

Yustiawan, A., Suastika, K., Nugroho, W.H., 2013. Fatigue Life Prediction of the Keel Structure of a Tsunami Buoy using Spectral Fatigue Analysis Method. Makara Seri Teknologi, Volume 17(2), pp. 79-86 